\title{
Determination of Ammonium and Nitrate Ions on Degraded Peat Soil by Termites Activities in Tanjung Leban, Bengkalis Regency
}

\author{
Sofia Anita, Fransisca, and Tengku Ariful Amri
}

\begin{abstract}
Indonesia, especially Riau Province has struggled with forest fire since 1997 which causes degradation of peat soil. Nowadays, peat soil in the Bengkalis District, Riau Province, has been partially degraded by repeated fires and land clearing so that the fertility decline. Therefore, it is necessary to improve the fertility of peat land. The aim of this research was to study the effect of the presence of the termite nest to the ecosystem degraded peat lands in the village of Tanjung Leban, Bengkalis Regency. Parameters measured were the content of ammonium and nitrate ions in soil samples around the termite nests using Auto-analyzer. The results of analysis of 10 termite nests showed that the ion content of $\mathrm{NH}_{4}{ }^{+}\left(\mathrm{H}_{2} \mathrm{O}\right), \mathrm{NH}_{4}{ }^{+}(\mathrm{KCl})$, and $\mathrm{NO}_{3}\left(\mathrm{H}_{2} \mathrm{O}\right.$ and $\mathrm{KCl}$ ) found in soil samples $\mathrm{S2}, \mathrm{S8}$ and $\mathrm{S10}$. Based on the results, it can be concluded that the termite nests found in this study site in general no significant impact on the increase of nitrogen in the soil using analysis of variance (ANOVA) and Duncan test at $\alpha=0.05$.
\end{abstract}

Index Terms-Ammonium, auto-analyzer, nitrate, peat, termites.

\section{INTRODUCTION}

Peatlands have a low fertility rate because of the relatively high acidity with a $\mathrm{pH}$ range of 3-5, as well as poor nutrient content, both macro and micro [1]. The mineral content of peat in Indonesia is generally less than $5 \%$ and the rest is organic matter [2]. Based on fertility, peat is less favorable for agriculture. However, the limitations of mineral soils cause the peat soil used for agriculture and plantation. Today, peat is used for many agricultural commodities, such as palm tree. Soil is a natural body derived from a mixture of organic and inorganic materials weathering results so as to provide water, air and nutrients for plants [3]. There are several types of soil found in Indonesia, such as humus soil, volcanic, alluvial, and peat.

According to [2], Indonesia is a country that has the largest tropical peat swamp land in the world, which is about 20.6 million hectares [4]. The peat lands are mostly found in the lowlands along the east coast of the island of Sumatra, especially in Riau is a province with the largest peat lands,

Manuscript received August 15, 2016; revised October 28, 2016. This work was supported in part by the U.S. Department of Commerce under Grant BS123456. Determination of Ammonium and Nitrate Ions on Degraded Peat Soil by Termites Activities in Tanjung Leban, Bengkalis Regency

Sofia Anita and T. Ariful Amri are with Chemistry Dept. University of Riau, Indonesia (e-mail: sofiaanita94@ gmail.com, t.ariful.amri@ lecturer.unri.ac.id).

Fransisca was with the University of Riau, Indonesia (e-mail: Fransiscalin92@gmail.com). namely 4,360,740.2 hectares, spread in 12 districts. [1] Bengkalis, the second largest area of peat land, has about $803,891.1$ acres of rubber, sago, and pineapples, so that increasing fertility is needed.

The use of fertilizers require an additional cost and may adversely affect the environment. The alternative is to burn plant litter and partially dried peat layer to produce ash that can improve soil productivity. However, it also had a negative impact because it can trigger a forest fire that eventually it will decrease soil fertility [2]. Using termites is a solution to increase environmentally friendly fertility without disrupting the continuity of the ecosystem. Termites are macrofauna soil that can survive in the acidic environment [5], such as peat. Habits of termites build nests with modifying organic material causes an increase in organic matter in the soil. The accumulation of organic matter will improve soil fertility in the nest location and surroundings. Termites affect the nitrogen cycle in the ecosystem for building the structure of biogenic-rich nutrients, especially inorganic nitrogen that can be used by plants [6].

Numerous studies have been done on termite nests, especially in areas of poor soil mineral nutrients. Research in Venezuela [7], Colombia [8], and Brazil [9] showed the content of $\mathrm{NH}_{4}^{+}$and $\mathrm{NO}_{3}$ in termite nests. However, research on nitrogen content in termite nests on peat soil, which also nutrient-poor, has not been studied in Tanjung Leban, Bengkalis Regency, Riau Province. This land generally has suffered repeated fires, causing degradation. Therefore, this study was conducted to determine the effect of the termite nest to increase the nitrogen content in the area. Research is done in degraded peatland fires in 2002, 2004 and 2007 in the village of Tanjung Leban.

\section{EXPERIMENTAL METHOD}

The instruments were used in this study were digital scales (Hanke YF - MB BL - 01), oven, desiccator, cup aluminum, centrifuge (AS ONE HSIANGTAI ), tube centrifuge plastic size $50 \mathrm{~mL}$ (IWAKI, Japan), $12 \mathrm{~mL}$ syringe, the filter paper (GF / F , $0.7 \mu \mathrm{m}$; Whatman, UK), disposable syringe filter unit $0.45 \mu \mathrm{m}$ (Cellulose acetate, ADVANTEC), filter holder (Polysulfone aseptic, ADVANTEC), automotive test $\&$ bleed kit (MODEL MV8000), Auto-analyzer (QuAAtro2-HR, BLTEC). Materials were a soil sample taken from degraded peatland in Tanjung Leban, Bengkalis Regency, $\mathrm{KCl}$ (p.a.), $\mathrm{NH}_{4} \mathrm{Cl}, \mathrm{Na}_{2}$ EDTA, $\mathrm{NH}_{4} \mathrm{OH}, \quad \mathrm{TX} 10, \mathrm{C}_{6} \mathrm{H}_{8} \mathrm{~N}_{2} \mathrm{O}_{2} \mathrm{~S}, \mathrm{H}_{3} \mathrm{PO}_{4}$ concentrated, $\quad \mathrm{C}_{12} \mathrm{H}_{14} \mathrm{~N}_{2 \cdot 2} \mathrm{HCl}, \quad \mathrm{KNaC}_{4} \mathrm{H}_{4} \mathrm{O}_{6} \cdot{ }_{4} \mathrm{H} 2 \mathrm{O}$, $\left(\mathrm{CH}_{2} \mathrm{COONa}\right)_{2} \cdot \mathrm{H}_{2} \mathrm{O}, \mathrm{H}_{2} \mathrm{SO}_{4}$ concentrated, $\mathrm{C}_{6} \mathrm{H}_{5} \mathrm{OH}, \mathrm{NaOH}$, 
$\mathrm{NaOCl}, \quad \mathrm{Na}_{4}\left[\mathrm{Fe}(\mathrm{CN})_{6} \mathrm{NO}_{2}\right] \cdot{ }_{10} \mathrm{H}_{2} \mathrm{O}, \mathrm{CuSO}_{4} \cdot{ }_{5} \mathrm{H}_{2} \mathrm{O}, \quad \mathrm{HCl}$, $\left(\mathrm{NH}_{4}\right)_{2} \mathrm{SO}_{4}, \mathrm{CHCl}_{3}, \mathrm{KNO}_{3}$, Milli-Q water.

This study was conducted in one of the degraded peatland $\left(0^{\circ} 44^{\prime}-1^{\circ} 11^{\prime} \mathrm{N}\right.$ and $\left.100^{\circ} 11^{\prime}-102^{\circ} 10^{\prime} \mathrm{E}\right)$ in Tanjung Leban, Bengkalis Regency. The land chosen as the study site was originally a peat used as oil palm plantations. Those plantations have been burned three times, namely in 2002, 2004 and 2007, causing land degradation. Sampling technique used is purposive sampling. A termite nest on the transect observed, then immediately do the soil sampling. Then, soil samples around the termite nest is taken and put in a ziplock bag. Soil samples on the transect do not have a termite nest is also taken as control. Three replicates were taken or each termite nests and control. Soil solution samples to be analyzed must be removed from the freezer and thawed prior to analysis. The time required for the liquefaction process depends on the number and volume of samples, usually around 1.5 hours. After melting, the sample is poured into the cup auto - analyzer. Each cup be filled with $1 \mathrm{~N} \mathrm{HCl}$ then be inhaled by the probe. After that, the cup filled with Milli-Q water and sucked bac out. Each stage is repeated 2 times.

Ammonium ion analysis carried out by Berthelot reaction. The formation of complex compounds is accelerated by heating it in a heating bath set at $37^{\circ} \mathrm{C}$. Further, the complex compounds formed indophenol blue flowed into photocolorimeter which has been set at a wavelength of 630 $\mathrm{nm}$. Recorder is also regulated by the speed chart $5 \mathrm{~cm} / \mathrm{min}$. Analysis of nitrate ions, samples are drawn into the system unloaded speed of $0.32 \mathrm{~mL} / \mathrm{min}$ to $0.1 \mathrm{~mL} / \mathrm{min}$. Reduction of nitrite ions results then flowed out the column and reacted with Sulfanilamide under acidic conditions to form a diazo compound. After that, the diazo compound binds to $\mathrm{N}$-(1-naphthyl)- ethylenediamine dihydrochloride to form a reddish purple azo dyes. These complex compounds absorb color at a wavelength of $550 \mathrm{~nm}$ so that the filter colorimeter set at these wavelengths and the chart recorder speed $5 \mathrm{~mm} / \mathrm{min}$. The content of nitrite ions were measured a combination of nitrate and nitrite ion content in the samples. Data were analysed using ANOVA.

\section{RESULTS AND DISCUSSION}

Results of the sampling are presented in Table I. In transect of $100 \mathrm{~m} \mathrm{x} 2 \mathrm{~m}$ made as sampling sites, found 10 nests of termites. It can be observed that the section of the transect can have more than one nest of termites, section 8,9 , and 10 . In addition, there are three types of termites found ten nests, which Schedorhinotermes sp., Coptotermes sp., and Parrhinotermes sp.

The content of ammonium and nitrate ions are extracted with deionized water and $1.372 \mathrm{~N} \mathrm{KCl}$ solution for each soil sample are presented in Table II. It shows that the highest content of ammonium ions are extracted with a $\left(\mathrm{NH}^{+}\left(\mathrm{H}_{2} \mathrm{O}\right)\right)$ were obtained from soil samples $\mathrm{S} 2$, ie $5.4275 \pm 6.51 \mathrm{mg} / \mathrm{kg}$. These results are in contrast to the content of ammonium ions extracted using a solution of $\mathrm{KCl}\left(\mathrm{NH}_{4}^{+}(\mathrm{KCl})\right)$ for the same soil sample. The highest content of $\mathrm{NH}_{4}{ }^{+}$ions $(\mathrm{KCl})$ were from to $45.4467 \pm 8.91 \mathrm{mg} / \mathrm{kg}$, found in soil samples $\mathrm{S} 8$
(Table II and Fig. 1). Both the soil samples contain ammonium ions are significantly different at $\alpha=0.05$ with the majority of other samples of ammonium ion content in each solvent extraction.

TABEL I: LOCATION AND TERMITES TYPES FOUND IN THE PEAT SOIL AT TANJUNG LEBAN

\begin{tabular}{cccc}
\hline $\begin{array}{c}\text { Nest } \\
\text { Number }\end{array}$ & Code & Location & Termites Types \\
\hline 1 & $\mathrm{~S}_{1}$ & Section 2 & Schedorhinotermes $\mathrm{sp}$. \\
2 & $\mathrm{~S}_{2}$ & Section 6 & Coptotermes $\mathrm{sp}$. \\
3 & $\mathrm{~S}_{3}$ & Section 7 & Schedorhinotermes $\mathrm{sp}$. \\
5 & $\mathrm{~S}_{4}$ & Section 8 & Schedorhinotermes $\mathrm{sp}$. \\
6 & $\mathrm{~S}_{5}$ & Section 8 & Schedorhinotermes $\mathrm{sp}$. \\
7 & $\mathrm{~S}_{6}$ & Section 9 & Schedorhinotermes $\mathrm{sp}$. \\
8 & $\mathrm{~S}_{7}$ & Section 9 & Schedorhinotermes $\mathrm{sp}$. \\
9 & $\mathrm{~S}_{8}$ & Section 10 & Schedorhinotermes $\mathrm{sp}$. \\
10 & $\mathrm{~S}_{9}$ & Section 10 & Schedorhinotermes $\mathrm{sp}$. \\
\hline
\end{tabular}

TABLE II: AMMONIUM AND NITRATE IONS (MEAN \pm STANDARD DEVIATION, $\mathrm{N}=3$ ) AND ITS CONTROL

\begin{tabular}{|c|c|c|c|}
\hline \multirow[t]{2}{*}{ Code } & \multirow[t]{2}{*}{$\begin{array}{c}\text { Water } \\
\text { content } \\
(\%)\end{array}$} & \multicolumn{2}{|r|}{$\begin{array}{c}\mathrm{NH}_{4}^{+} \\
(\mathrm{mg} / \mathrm{kg})\end{array}$} \\
\hline & & $\mathbf{H}_{2} \mathbf{O}$ & $\mathrm{KCl}$ \\
\hline $\mathrm{S}_{1}$ & 27,43 & $0,6504 \pm 0,09^{b}$ & $6,4824 \pm 3,52^{b c}$ \\
\hline $\mathrm{S}_{2}$ & 29,20 & $5,4275 \pm 6,51^{a}$ & $24,8023 \pm 17,471$ \\
\hline $\mathrm{S}_{3}$ & 31,33 & $0,5359 \pm 0,09^{b}$ & $5,9534 \pm 1,79 \mathrm{bc}$ \\
\hline $\mathrm{S}_{4}$ & 41,30 & $3,2391 \pm 1,08^{2 b}$ & $19,6570 \pm 6,82^{b c}$ \\
\hline $\mathrm{S}_{5}$ & 41,30 & $0,8949 \pm 0,28^{b}$ & $8,1863 \pm 10,74^{1}$ \\
\hline $\mathrm{S}_{6}$ & 33,17 & $0,8219 \pm 0,53^{b}$ & $4,7960 \pm 1,82^{c}$ \\
\hline $\mathrm{S}_{7}$ & 33,17 & $0,6464 \pm 0,13^{b}$ & $4,4169 \pm 2,39 c$ \\
\hline $\mathrm{S}_{8}$ & 28,87 & $0,6223 \pm 0,13^{b}$ & $45,4467 \pm 8,91^{\mathrm{a}}$ \\
\hline $\mathrm{S}_{9}$ & 28,87 & $0,4460 \pm 0,22^{b}$ & $12,5622 \pm 16,47^{1}$ \\
\hline $\mathrm{S}_{10}$ & 27,07 & $0,6764 \pm 0,05^{b}$ & $15,8609 \pm 6,34^{b c}$ \\
\hline $\mathrm{K}_{1}$ & 18,94 & $0,7150 \pm 0,46^{b}$ & $13,0160 \pm 14,44^{\prime}$ \\
\hline $\mathrm{K}_{2}$ & 20,68 & - & - \\
\hline Code & \multicolumn{3}{|c|}{$\begin{array}{c}\mathrm{NO}_{3}^{-} \\
(\mathrm{mg} / \mathrm{kg})\end{array}$} \\
\hline \multicolumn{3}{|c|}{$\mathbf{H}_{2} \mathbf{O}$} & $\mathrm{KCl}$ \\
\hline $\mathrm{S}_{1}$ & \multicolumn{2}{|c|}{$0,0367 \pm 0,06^{c}$} & $0,3271 \pm 0,37^{d}$ \\
\hline $\mathbf{S}_{2}$ & \multicolumn{2}{|c|}{$2,9379 \pm 2,25^{b c}$} & $5,5819 \pm 1,80^{\mathrm{bc}}$ \\
\hline $\mathrm{S}_{3}$ & \multicolumn{2}{|c|}{$0,0543 \pm 0,05^{c}$} & $0,4272 \pm 0,43^{d}$ \\
\hline $\mathrm{S}_{4}$ & \multicolumn{2}{|c|}{$6,4963 \pm 1,91^{\mathrm{ab}}$} & $8,2180 \pm 0,35^{\mathrm{ab}}$ \\
\hline $\mathrm{S}_{5}$ & \multicolumn{2}{|c|}{$0,0000 \pm 0,00^{c}$} & $0,1545 \pm 0,14^{d}$ \\
\hline $\mathrm{S}_{6}$ & \multicolumn{2}{|c|}{$0,0080 \pm 0,01^{c}$} & $0,4828 \pm 0,43^{d}$ \\
\hline $\mathrm{S}_{7}$ & \multicolumn{2}{|c|}{$1,9431 \pm 2,54^{c}$} & $5,3626 \pm 0,78^{b c}$ \\
\hline $\mathrm{S}_{8}$ & \multicolumn{2}{|c|}{$0,8885 \pm 1,46^{c}$} & $1,0234 \pm 0,79^{d}$ \\
\hline $\mathrm{S}_{9}$ & \multicolumn{2}{|c|}{$1,2146 \pm 1,03^{c}$} & $3,3289 \pm 2,52^{\mathrm{cd}}$ \\
\hline $\mathrm{S}_{10}$ & \multicolumn{2}{|c|}{$9,2101 \pm 1,99^{\mathrm{a}}$} & $11,8902 \pm 2,56^{\mathrm{a}}$ \\
\hline $\mathrm{K}_{1}$ & \multicolumn{2}{|r|}{-} & - \\
\hline $\mathrm{K}_{2}$ & \multicolumn{2}{|c|}{$3,6173 \pm 4,34^{b c}$} & $6,6519 \pm 5,13^{\mathrm{bc}}$ \\
\hline
\end{tabular}

The content of nitrate ions which extracted with deionized water $\left(\mathrm{NO}_{3}\left(\mathrm{H}_{2} \mathrm{O}\right)\right)$ showed that the highest values in 1 soil 
samples S10, namely $9.2101 \pm 1.99 \mathrm{mg} / \mathrm{kg}$ (Table II and Fig. 1). Meanwhile, in soil samples $S 5$ was not measured any ions $\mathrm{NO}_{3}\left(\mathrm{H}_{2} \mathrm{O}\right)$. Soil samples $\mathrm{S} 10$ not only show the highest nitrate ion content in the extract deionized water, but also on the extract solution of $\mathrm{KCl}$, which ranged from $11.8902 \pm$ $2.56 \mathrm{mg} / \mathrm{kg}$ (Table II and Fig 2. Based on Duncan test, nitrate ions content in soil samples S10, whether extracted with deionized water or $\mathrm{KCl}$ solution, differs significantly $(\alpha=0.0)$ with most of the nitrate ion content of more soil samples.
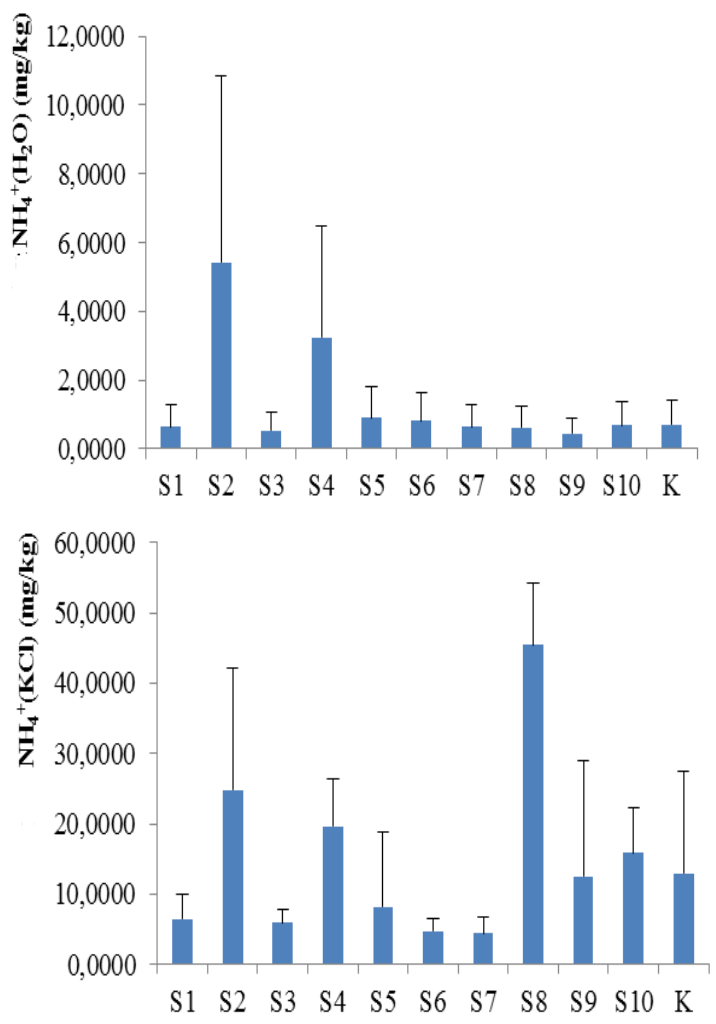

Fig. 1. The mean of $\mathrm{NH} 4+(\mathrm{KCl})$ (left) and $\mathrm{NH} 4+(\mathrm{KCl})$ (right) concentrations $(n=3)$ on termites nest and its control.
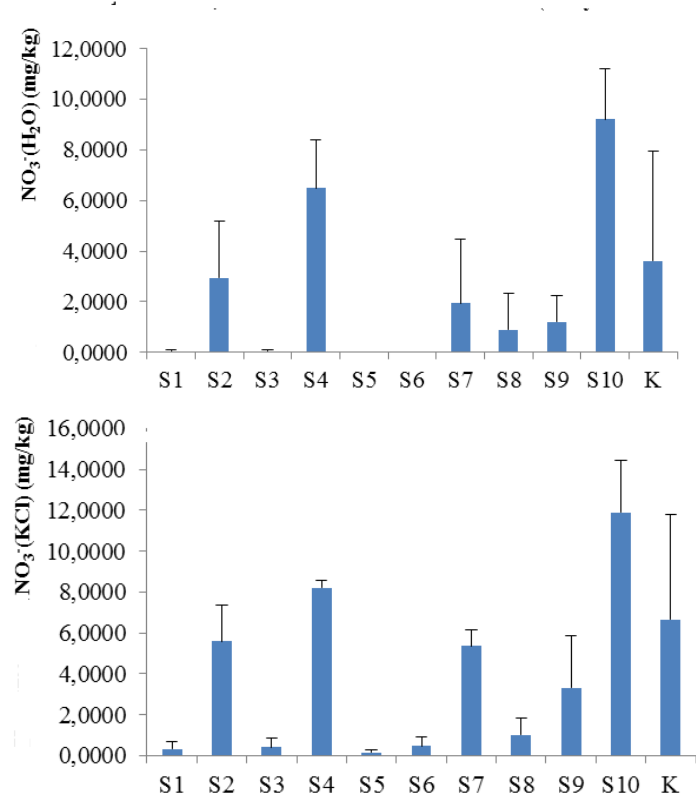

Fig. 2. The mean of NO3-(H2O) (left) and NO3- $(\mathrm{KCl})$ (right) concentrations $(n=3)$ on termites nest and its control.

The content of ammonium ions contained in soil samples around the termite nests are found on the whole did not differ from controls. Based on Duncan test, only the content of ion $\mathrm{NH}_{4}{ }^{+}\left(\mathrm{H}_{2} \mathrm{O}\right)$ in soil samples $\mathrm{S} 2(5.4275 \pm 6.51 \mathrm{mg} / \mathrm{kg})$, which has significant differences to the control at $\alpha=0.05$. Similar results were also shown by the content of $\mathrm{NH}_{4}{ }^{+}$ions $(\mathrm{KCl})$. Soil samples S8 is the only one that showed significant differences to the control. Each soil sample analyzed contains $\mathrm{NH}_{4}^{+}\left(\mathrm{H}_{2} \mathrm{O}\right)$ ion $(\mathrm{KCl})$ which is much higher than the $\mathrm{NH}_{4}^{+}$ $\left.\left(\mathrm{H}_{2} \mathrm{O}\right)\right)$. This is because the positively charged ammonium ions which are generally tied strongly with negatively charged soil colloids [10] so, deionized water can not be extracted. However, the content of ions $\mathrm{NH}_{4}^{+}\left(\mathrm{H}_{2} \mathrm{O}\right)$ ) measured shows that most of the ammonium ion is in a free state in the country even though its concentration is low. In contrast, $\mathrm{KCl}$ solution has a potassium ion is also positively charged so as to extract the ammonium ions are bound in the soil through cation exchange reaction. The reason of choosing $\mathrm{KCl}$ as a solvent extractor is because potassium and ammonium ion size almost the same so that the cation exchange will be more apt to occur [11].

The content of nitrate ions derived from most soil samples around the nests of termites also showed no significant difference against the control. S10 soil samples containing ions $\mathrm{NO}_{3}\left(\mathrm{H}_{2} \mathrm{O}\right)$ and $\mathrm{NO}_{3}(\mathrm{KCl})$ each by $9.2101 \pm 1.99 \mathrm{mg} / \mathrm{kg}$ and $11.8902 \pm 2.56 \mathrm{mg} / \mathrm{kg}$ did not differ significantly $(\alpha=0,05)$ with the control. Meanwhile, the nitrate ion content in all the other soil samples did not have significant differences with the control. The pattern of nitrate ion content of each sample was ground together with the ammonium ion content, the content of ions $\mathrm{NO}_{3}(\mathrm{H} 2 \mathrm{O})$ is lower than the ion $\mathrm{NO}_{3}(\mathrm{KCl})$. The results obtained are not consistent with the fact that the nitrate ion which is usually in the form of free land should be extracted only by using deionized water. This is likely due to time shaking long enough so that not all of nitrate ions in soil samples that were extracted out. Meanwhile, the positively charged potassium ions in $\mathrm{KCl}$ solution will also facilitate the extraction process due to an ionic bond with the nitrate ions are negatively charged. Nevertheless, almost all soil samples, except S7 and S10, has a nitrate ion content lower than the ammonium ion, which indicates that ammonification and denitrification is higher than the nitrification in the soil [7].

Results obtained in this study are generally lower than studies in the area of mineral soil. [12] in the Colombian jungle show that the ion content of $\mathrm{NH}_{4}{ }^{+}$and $\mathrm{NO}_{3}$ in the soil within $20 \mathrm{~cm}$ from the edge of the mound Nasutitermes $s p$. row is about $45 \mathrm{~g} / \mathrm{g}$ and $40 \mathrm{mg} / \mathrm{g}$. Meanwhile, research on termite nests Nasutitermes ephratae in Sabana Venezuela by [7] concluded that the soil around the nest of termites have $\mathrm{NH}_{4}{ }^{+}$ion content of $29.5 \mathrm{~g} / \mathrm{g}$. Based on this data, only soil samples $\mathrm{S} 8$ which contains $\mathrm{NH}_{4}{ }^{+}$ion equivalent or higher than the research [7] and [12]. The low content of ammonium and nitrate ions are measured in this study may be due to the limited termite species that can live in conditions of acid soils. Termites are found at the study site consists of Schedorhinotermes sp., Coptotermes sp., and Parrhinotermes $s p$. The types of termites belong to the wood-eating group that also make nests in wood, vary with the type of termites in other studies that make mounds. Nesting inside the timber causes nutrients accumulate in the nest difficult to move into the surrounding soil. Therefore, the types of termites were less contribute to the increased content of ammonium and nitrate 
ions into the ground.

Termites are decomposing organisms that contribute significantly to the nutrient cycle in tropical ecosystems [9]. In the mineral soil, termites make a tunnel that will increase groundwater recharge [6] decomposing plant litter, and build mounds through translocation will enrich soil nutrients [13]. Research conducted by [12] against Nasutitermes $s p$. revealed that termite mounds can act as a source of nitrogen for plants runoff in the savanna ecosystems that poor nutrition. The content of ammonium and nitrate ions obtained in this study are generally quite low. According [14], nitrate ion content in the range of 0.0000 to $11.89 \mathrm{mg} / \mathrm{kg}$ were in the criteria is very low ( $<5 \mathrm{ppm})$ to low $(5-15 \mathrm{ppm})$. In addition, the content of ammonium and nitrate ions are measured as a whole did not differ from controls so that the role of termites to increase the nitrogen content in degraded peat soil at the site of research yet to be seen.

Set of termite found in this study site only from Rhinotermitidae family consisting of three genera, namely Schedorhinotermes, Coptotermes, and Parrhinotermes. All types of termite found a diet of wood and termites nesting in the wood are thus the pest termites that actually have a negative impact on the environment. The low abundance of species of termites in the study site can be caused by disturbances during the clearing process or multiple fires that caused the death of another termite species that are susceptible to interference. Disturbance on degraded peat lands may have reduced termite functional groups, such as Macrotermes and Nasutitermes, which is important in improving soil nutrient. Peat soil is acidic limiting organisms that can live there. Earthworms as one of the decomposing organisms that have the same role with the termites are very sensitive to acidic $\mathrm{pH}$ conditions, anaerobic, and other disorders [15] so it is hardly found in degraded peat lands. Meanwhile, ground-eating termite studies in Sabana Colombia revealed that the group is more important termites in the improvement of soil nutrients than ants [8]. Therefore, termites seen as decomposing organisms that can be used efficiently in the peat soil. However, it is necessary to take measures to increase the abundance of species of termites are functional and reduce termite pest so that the role of termites on soil fertility can be improved.

\section{CONCLUSION}

Termite nests were found at the study site in general no significant impact on the increase of nitrogen in the soil around by analysis of variance (ANOVA) and Duncan test using SPSS at $\alpha=0.05$.

\section{ACKNOWLEDGEMENT}

Funding for this project was provided by Center for Southeast Asian Studies Kyoto University. It is also supported by University of Riau's Rector and Faculty of Maths and Natural Sciences Dean.

\section{REFERENCES}

[1] Mubekti, "Studi pewilayahan dalam rangka pengelolaan lahan gambut berkelanjutan di Provinsi Riau," Jurnal Sains dan Teknologi Indonesia, vol. 13, no. 2, pp. 88-94, 2011.

[2] F. Agus and I. G. M. Subiksa, Lahan Gambut: Potensi untuk Pertanian dan Aspek Lingkungan, Balai Penelitian Tanah dan World Agroforestry Centre (ICRAF), Bogor, 2008.

[3] Indriyanto, Ekologi Hutan, Bumi Aksara, Jakarta, 2006.

[4] Wahyunto, S. Ritung, Suparto, and H. Subagjo, Sebaran Gambut dan Kandungan Karbon di Sumatera dan Kalimantan, Wetlands International-Indonesia Programme dan Wildlife Habitat Canada, Bogor, 2005.

[5] D. T. Jones, and P. Eggleton, "Sampling termite assemblages in tropical forests: Testing a rapid biodiversity assessment protocol," Journal of Applied Ecology, vol. 37, pp. 191-203, 2000.

[6] O. Desouza and E. M. Cancello, Termites and Ecosystem Function, Encyclopedia of Life Support Systems (EOLSS) Publishers, Oxford, 2010.

[7] D. López-Hernández, Soil Biology \& Biochemistry, vol. 33, pp. 747-753, 2001.

[8] J. J. Jiménez, T. Decäens, and P. Lavelle, " $\mathrm{C}$ and $\mathrm{N}$ concentrations in biogenic structures of a soil-feeding termite and a fungus-growing ant in the Colombian Savannas," Applied Soil Ecology, vol. 40, pp. 120-128, 2008.

[9] I. L. Ackerman, W. G. Teixeira, S. J. Riha, J. Lehmann, and E. C. M. Fernandes, "The impact of mound-building termites on surface soil properties in a secondary forest of Central Amazonia," Applied Soil Ecology, vol. 37, pp. 267-276, 2007.

[10] A. Fauzi, "Analisa kadar unsur hara karbon organik dan nitrogen di dalam tanah perkebunan kelapa sawit Bengkalis Riau," Skripsi. Jurusan Kimia, Fakultas Matematika dan Ilmu Pengetahuan Alam, Universitas Sumatera Utara, Medan, 2008.

[11] S. Isnaini, "Kandungan amonium dan kalium tanah dan serapannya serta hasil padi akibat perbedaan pengolahan tanah yang dipupuk nitrogen dan kalium pada tanah sawah,” Jurnal Ilmu-ilmu Pertanian Indonesia, vol. 7, no. 1, pp. 23-34, 2005.

[12] J. J. Jiménez, T. Decäens, and P. Lavelle, "Nutrients spatial variability in biogenic structures of Nasutitermes (Termitinae; Isoptera) in a gallery forest of the Colombian 'Llanos'," Soil Biology \& Biochemistry, vol. 38, pp. 1132-1138, 2006.

[13] D. Rückamp, W. Amelung, and L. S. Borma, "Carbon and nutrient leaching from termite mounds inhabited by primary and secondary termites," Applied Soil Ecology, vol. 43, pp. 159-162, 2009.

[14] A. Rosmarkam and N. W. Yuwono, Ilmu Kesuburan Tanah, Penerbit Kanisius, Yogyakarta, 2002.

[15] E. Handayanto and K. Hairiah, Biologi Tanah: Landasan Pengelolaan Tanah Sehat, Pustaka Adipura, Yogyakarta, 2009.

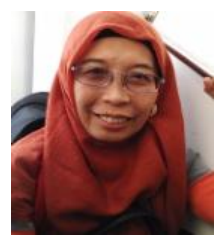

Sofia Anita was born in Sungai Pakning, Bengkalis Regency on April 20, 1965. She is a lecturer at Chemistry Dept. Faculty Maths and Natural Sciences, University of Riau. She got the diploma in chemistry from University of Riau, Indonesia in 1989, the master's degree from University of Manchester, UK in 1998; and the PhD from Universiti Putra Malaysia, Malaysia in 2009. Her major is environmental chemistry. In 2011-2014, she was a head of Chemistry Dept. University of Riau. Since 2015 until now, she is a secretary of International Office at University of Riau.

Dr. Sofia Anita's research interests are environmental, especially oil spill fingerprinting. Nowaday, she is more interested in forest fires. 